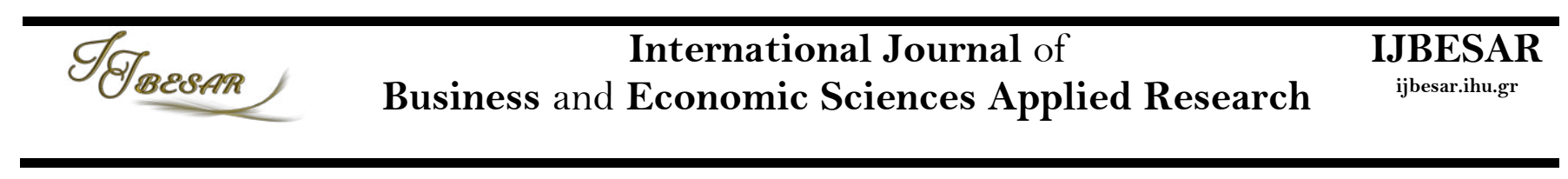

\title{
Corruption and Foreign Direct Investment Inflows: Evidence from West Africa
}

\author{
William Bekoe $^{\dagger 1}$, Talatu Jalloh ${ }^{2}$, Wassiuw Abdul Rahaman ${ }^{1}$ \\ ${ }^{1}$ Department of Economics, University of Ghana \\ ${ }^{2}$ Post-graduate Student, Department of Economics, University of Ghana
}

\begin{tabular}{l}
\hline ARTICLE INFO \\
\hline Article History \\
Received 20 April $2021 ;$ \\
Accepted 21 September 2021 \\
JEL Classifications \\
H6, H63, H68
\end{tabular}

ABSTRACT

Purpose:
The study investigates the effect of corruption on FDI inflows to West Africa, and also
establishes a threshold level of corruption for the sub-region.
Design/Methodology/Approach:
Using secondary data for the period 1999-2018, the study adopted a panel Autoregressive
Distributed Lag (ARDL) model to carry out regression analysis. However, to ensure
results accuracy and validity, a cross section dependence test, panel unit root test and
panel cointegration test was carried out.

Findings:

The results indicated that in the long-run, corruption adversely affects the inflow of FDI to West Africa, thus lending support to the grabbing hand hypothesis. The study found the long-run threshold level of corruption for West Africa to be 6.3, indicating that below this level FDI inflow cannot be discouraged by corruption otherwise, FDI inflows could be discouraged.

\section{Research limitations/Implications:}

The findings from the study suggests that governments from West Africa should focus on mechanisms that will strongly discourage people from engaging in corruption, such as reducing the delays in business registration, strengthening and ensuring of effective monitoring of public institutions, as well as introducing the practice of penalty and exhortation in the public sector.

\section{Quality/Value:}

Keywords:

Foreign Direct Investment, Corruption, Corruption Threshold, West Africa, Panel Autoregressive Distributed Lag (ARDL) Model on the inflow of FDI to West Africa using a more appropriate macro panel estimation technique, the panel Autoregressive Distributive Lag (ARDL) technique. Furthermore, it provides a threshold level for corruption on FDI inflows in West Africa.

\section{Introduction}

Foreign Direct Investment (FDI) has over the years become a highly sought-after resource, especially in developing countries, due to its tendency to stimulate growth, provide jobs and transfer technology and skills (Akonnor, 2018; 
UNCTAD 2010; Ayanwale, 2007). Statistics from the United Nations Conference on Trade and Development [(UNCTAD) 2019] show a remarkable growth in global FDI inflows over the past decades. A similar experience is observed for Africa and other developing regions. Nevertheless, the African continent lag in terms of the value of FDI inflows it receives in comparison to Asia, Latin America and the Caribbean. Besides that, the data showed that FDI inflow across sub-regions in Africa varies substantially. For instance, between 1999-2018, North Africa attracted an annual FDI inflow of around US $\$ 12$ billion on average (representing 2.3\% of its GDP); West Africa (US\$9 billion, being $2.2 \%$ of GDP); East Africa (US $\$ 8$ billion and $3.5 \%$ as a share of GDP); Southern Africa (US $\$ 5$ billion and $1.7 \%$ as a share of GDP); and Central Africa (US\$4 billion and $3.7 \%$ as a share of GDP).

Despite being the second-largest recipient of FDI in Africa, the amount of FDI flow into West Africa has been declining consistently since 2011 (see UNCTAD Stats, 2019). Between 2011 and 2018, for instance, FDI inflows to the sub-region declined by almost by $50 \%$. In 2018 alone, despite the $11 \%$ increase in FDI inflows to Africa, the sub-region experienced a whopping $15 \%$ decline in FDI inflows-the lowest over the period. The level of FDI inflows to the subregion also constituted 1.5\% of GDP compared to the sub-Saharan African levels of 2.4\% of GDP and the World's average of $2.3 \%$ over the period 1999 to 2018. The situation is worrisome, more so, when the continent of Africa has been identified as a major recipient of FDI towards the realization of the Africa Continental Free Trade Area Agreement (ACFTAA) (UNCTAD, 2019). Aside from that, the current trend compromises each country's effort to achieve the Sustainable Development Goals (SDGs) and become non-aid reliant.

Moreover, most of the countries in the West African sub-region are highly endowed with natural and mineral resources - a major attraction for FDI inflows (Dunning, 2000; Asiedu, 2006; Anyanwu, 2011). However, equally important in influencing FDI inflows is the level of corruption (Asiedu 2006²; Fahad and Ahmed, 2016; Okafor et al., 2017; Largarde, 2017), since it can serve as a useful yardstick for assessing the business climate in a country (International Finance Corporation: World Bank Group, 2019). It can starve countries of genuine investors and further inhibit societal progress (Andvig, 2008). Furthermore, it has been suggested that many African countries attract less FDI due to rampant corruption, poor and non-growing economies (UNCTAD, 2001 as cited by Habib and Zurawicki, 2002). Although no country is immune from corruption, the practice, however, is more widespread in Africa (Hanson, 2009), of which West Africa is no exception.

Two strands of arguments exist in the literature regarding the effect of corruption on FDI inflows, namely the Grabbing Hand Hypothesis (see, Mosikari and Eita, 2018; Luu et al.,2019 and Kasasbeth et al., 2018) and the Helping Hand Hypothesis (see, Omodero, 2019; Gossel,2018; Donaubauer et al.,2018 and Hasan et al., 2017). Whilst the former argues that corruption deters FDI, the latter contends that corruption encourages FDI inflows. Aside from empirical findings lacking consensus on this debate, empirical studies on the subject area are also biased towards global, regional, national and firm-level studies, against sub-regional level studies (see Quazi et al., 2014, Fahad and Ahmad, 2017; and Epaphra and Massawe, 2017). The need to conduct a sub-regional analysis independently, therefore, becomes paramount especially when sub-regions have diverse cultures with distinct regulatory environment (Anyanwu and Yameogo, 2015). Moreover, it is evident from the literature that studies that employed macro panel data in the subject area (see, Quazi et al., 2014; Fahad and Ahmed, 2016; Gossel, 2018), ignored the possibility of correlation between residuals in different cross-sectional units (see Pesaran, 2004) and slope heterogeneity ${ }^{3}$, partly due to the estimation techniques adopted. The consequence is the possibility of compromising on the validity and accuracy of results. More so, there is lack of consensus in the literature on the minimum level/threshold of corruption beyond which FDI inflows into a region could be discouraged.

In view of the above, the present study seeks to fill the literature gaps in the subject area by investigating the effects of corruption on the inflow of FDI to West Africa, by adopting the panel Autoregressive Distributive Lag (ARDL) technique. The study also attempts to establish a minimum level/threshold of corruption beyond which FDI inflows into West Africa could be discouraged. Recommendations from the study would not only serve as useful guide to governments and policymakers, but also for potential foreign investors into the West African sub-region and Africa at large.

The study progress as follows: A review of related studies is presented in Section 3; an overview of corruption and FDI in West Africa in Section 3; Section 4 presents the methodology which consists of theoretical framework, empirical

\footnotetext{
2 According to two separate surveys conducted by the World Business Environment (WBE) and the United Nations Conference on Trade and Development (UNCTAD) on thousands of firms in 1999/2000, Asiedu (2006) observed that corruption ranks highest as a constraint to FDI inflows to Africa on each survey.

${ }^{3}$ Standard panel estimation techniques, fixed effect, random effect and General Methods of Moments (GMM), assume slope homogeneity (Eberhardt, 2011).
} 
model specification, estimation technique and data sources; Section 5 presents and discusses the results, whilst Section 6 provides the conclusion and recommendations for the study.

\section{Literature Review}

Over the years, several theories have been propounded in the quest to understanding the activities of FDI. Examples include the Product Life Cycle Theory (Vernon, 1966), the Market Imperfection Theory (Hymer, 1976) and the Internationalization Theory (Buckley and Casson, 1976). Common among these theories is the idea that the willingness of firms to engage in foreign investment is directly or indirectly influenced by the possibility of capitalizing on some form of monopoly advantage. However, the most widely adopted theory for explaining FDI activities is the Eclectic Paradigm, developed and refined by Dunning (1977, 1995, 2000).

Dunning (2000) posits that the extent, geography and industrial composition of FDI undertaken by Multination Enterprises (MNEs) are contingent on the configuration of three sets of advantages: ownership, locational and internalization. Ownership advantage $(\mathrm{O})$, refers to the competitive advantage of the firm seeking to engage in FDI, in terms of production technique and innovative capabilities. Thus, the greater the competitive advantage of the firm investing, relative to domestic firms, the likelier they are to engage in FDI. Locational advantage (L) refers to the attractiveness of alternative countries or regions for FDI, because of the existence favourable investment climate such as: large market size, lower transportation and communication costs, better infrastructure, favourable trade policies towards FDI, fiscal incentives, political stability, quality institutional set-up, macroeconomic stability (Vernon 1966; Dicken and Lloyd, 1977). Internalization advantage (I), provides firms with alternative ways to organize the creation and exploitation of their core competencies, given the locational advantages of different countries or region.

Moreover, corruption is identified as one of the determinants of locational advantage (Habib and Zurawicki, 2002), but the association between corruption and FDI remains unclear and mainly divided along two strands of hypotheses, namely, the Grabbing Hand Hypothesis (GHH) and Helping Hand Hypothesis (HHH). In support of the former, Shleifer and Vishny (1993) argue that corruption acts as an unofficial tax burden, thus more distortionary and costly than tax, due to its illegality and secrecy on an investor. In a country with corruption-induced uncertainty, a firm's profit is likely to be eroded (Wei, 1997). Nonetheless, Bardhan (1997), Lui (1985), Leff (1964) argue in favour of the latter. For example, Bardhan (1997) argue that in a rigid administration with pervasive and cumbersome regulations, corruption can be the necessary grease for the system's squeaking wheels. Also, jurisdictions with weak tax enforcement mechanism, paying bribes might help firms avoid the constraints imposed by an excessive government through taxes (Goodspeed et al., 2011).

Empirical evidence on the corruption-FDI nexus is mainly divided between the GHH and HHH. In support of the GHH, Hines (1995) conducting a firm-level study and Habib and Zurawicki (2000) in a global level study found corruption to deter FDI. However, both studies adopted cross-sectional estimation techniques, which ignore the possibility of unobserved time-invariant effects. By using panel data techniques, the study by Asiedu (2006) found corruption to negatively impact FDI inflows. Similar finding was observed in two global studies by Fahad and Ahmed (2016) and Luu et al., (2019). The study by Abotsi and Iyavarakul (2015) did not only find corruption to impact negatively on FDI, but further established a threshold level for corruption in Africa, using the quadratic method. The study found the threshold level to be 44.5 on a scale of o (most corrupt) to 100 (least corrupt). Below this level, the study suggests that corruption will deter FDI inflows; but otherwise, if it is above that level. Oktay (2017) on the other hand, found high levels of corruption to have an ultimate negative effect on FDI, despite finding an initial positive effect for both former Soviet Union countries, and the Central and Eastern European countries.

Ignoring the immoral and unethical side of corruption, some studies have revealed that corruption can encourage FDI, in line with the helping hand hypothesis. For example, Omodero (2019) and Hasan et al., (2017) found corruption to significantly encourage FDI inflows for Nigeria and China respectively. However, the study by Hasan et al., (2017) has a strong possibility of suffering from omitted variable bias as the authors failed to include relevant control variables in the estimated model. Also, Gossel (2018) found corruption to be attractive for foreign investors in Africa, due to the weak regulatory framework ${ }^{4}$. Meanwhile, Cuervo-Cazurra (2008) suggested that the helping hand hypothesis is more prevalent in developing countries, where appropriate market institutions are yet to be fully established.

In conclusion, it was evident from the literature review that the relationship between corruption and FDI has no consensus. Also, dearth on sub-regional studies exists, while panel studies ignored the possibility of cross-section dependence and slope heterogeneity (Eberhardt, 2011). Therefore, besides augmenting the few existing sub-regional

\footnotetext{
${ }^{4}$ However, the study revealed that as democratic capital accumulates, the usefulness of this association might be outlived, and over time, corruption will become a deterring factor in attracting FDI inflows.
} 
studies, the study also adopts the panel Autoregressive Distributed Lag (ARDL) model, to remedy the aforementioned methodological challenges.

\section{Overview of FDI and Corruption in West Africa}

\section{FDI in West Africa}

West Africa remains one of the most strategic and influential sub-regions in Africa. Most of the countries in West Africa sit along the Atlantic Ocean, thus, facilitating trade. Also, it plays host to some of the biggest economies in Africa, as well as countries that are highly endowed in minerals and natural resources, such as, Ghana (gold), Nigeria (oil), Niger (uranium), Guinea (Bauxite), and so on (Jalloh, 2013). This makes the sub-region an attractive spot for FDI operations.

However, it is until recently that the sub-region's fame with FDI inflows came into the limelight. (see Figure 1). In the 1970 s and 1980 s, FDI inflows into the sub-region averaged US $\$ 520$ million (representing $0.57 \%$ of GDP) and US $\$ 705$ million (0.51\% of GDP) respectively. However, by the 1990 s, after years of severe economic struggles, countries in the sub-region adopted series of economic reforms in line with recommendations from the Bretton Wood Institutions (Heidhues and Obare, 2011). Since then, FDI inflows to the sub-region has improved significantly (Figure 1). In the 1990s FDI inflows was US\$2.1 billion (representing $2 \%$ of GDP) on average, accounting for over US $\$ 1.4$ billion more than the 1970 s and 1980 s levels. The amount of FDI inflows tripled between 2000-2009 to US $\$ 6.5$ billion (representing $2.3 \%$ of GDP). As evident from Figure 1, however, since 2011, the sub-region has consistently experienced a decline in FDI inflows. Between 2011 and 2018, the value of FDI inflows fell by 50\%, while the 2018 value was the lowest for over a decade (UNCTAD, 2019).

However, there is a stark difference among FDI recipients within the sub-region. The top three recipient countries, between 1999 and 2018 on average, are Nigeria with FDI inflows of US\$4 billion, Ghana (US\$2 billion) and Cote d'Ivoire (US\$400 million), while Guinea Bissau accounted for the lowest, US\$13 million (UNCTAD statistics, 2019). These countries together account for almost $70 \%$ of the FDI inflows into the sub-region, as they constitute the mineral and natural resource-rich countries (see UNCTAD statistics, 2019). For example, in 2018, Ghana's US\$2.9 billion FDI inflow was primarily channelled to the natural and mineral resource sector, while Nigeria enjoyed reinvestment earning by major oil companies (UNCTAD, 2019). Nevertheless, FDI inflows as a share of GDP for Liberia accounted for $23.8 \%$ of GDP on average from 1999 to 2018, followed by Cape Verde (7.5\%), Sierra Leone (6.8\%), Niger (5.7\%) and Guinea (3.9\%).

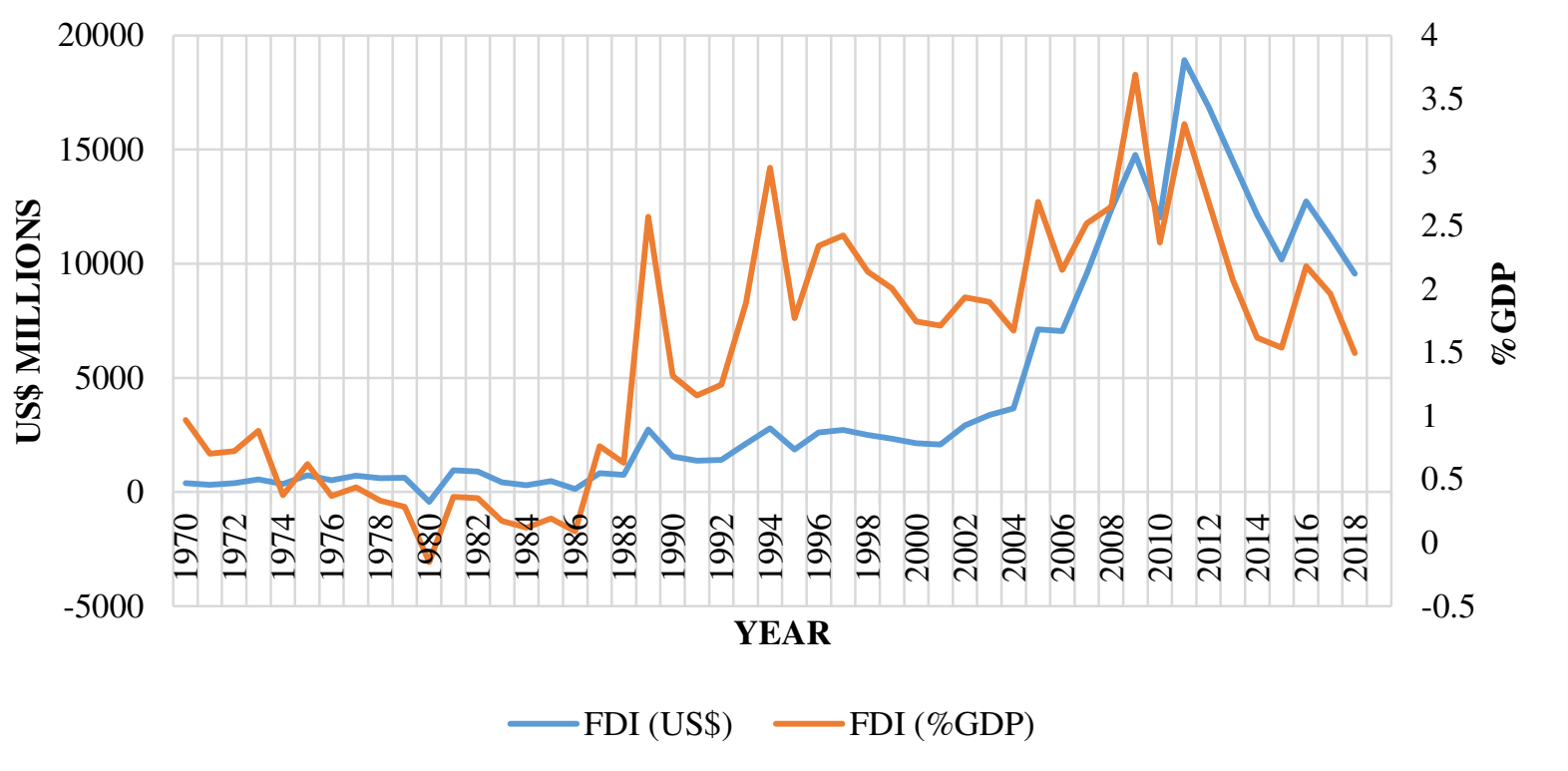

Figure 1: FDI Inflow trends into West Africa in value term and as a percentage of GDP (1970-2018).

Source: Authors' computation using UNCTAD statistics, (2019)

Corruption in West Africa 
Corruption is one of the major obstacles facing countries, not only because it inhibits a country's ability to attract FDI inflows, but also due to its tendency to undermine and distort public policy, which can lead to resource misallocation (Largarde, 2017. West African countries are no exception to corruption, and in fact, instances of corruption are many and widespread in all forms ${ }^{5}$ in majority of the countries (see Global Corruption Report, 2009; Chêne, 2010; Pring and Vrushi, 2019; Rahman, 2019). By employing available corruption data from the World Bank, Transparency International and other sister institutions, Figure 2 shows the average corruption scores amomg West African countries. It evident from the figure that it is only Cape Verde that reported a positive average corruption score of 0.78 , making it the least corrupt country in the sub-region. The rest of the countries occupy the negative segment on the number line, indicative of the extent of corruption in the sub-region. Guinea Bissau had the least average corruption score of -1.27 , making it the most corrupt country in the sub-region. The average corruption score for the West African sub-region of -0.62 for the period 2000-2018, performs poorly compared with South Africa's score of -0.25, Eastern Africa's average score of -0.53 and the North African average score of (-0.56).

In recent times, however, efforts to combat this menace have been stepped up by several countries. For instance, West African countries are party to the African Union Convention on Preventing and Combating Corruption (AUCPCC), as well as the United Nations Convention Against Corruption (UNCAC). Furthermore, most countries in the sub-region have established Anti-Corruption Agencies; Auditor General Offices; enacted public procurement acts; and created more space for civil society organizations, the media and opposition parties to participate in the governance process of respective countries (Lee-Jones, 2019; Shipley, 2018a and 2018b; Global Corruption Report, 2009; Chêne, 2010).

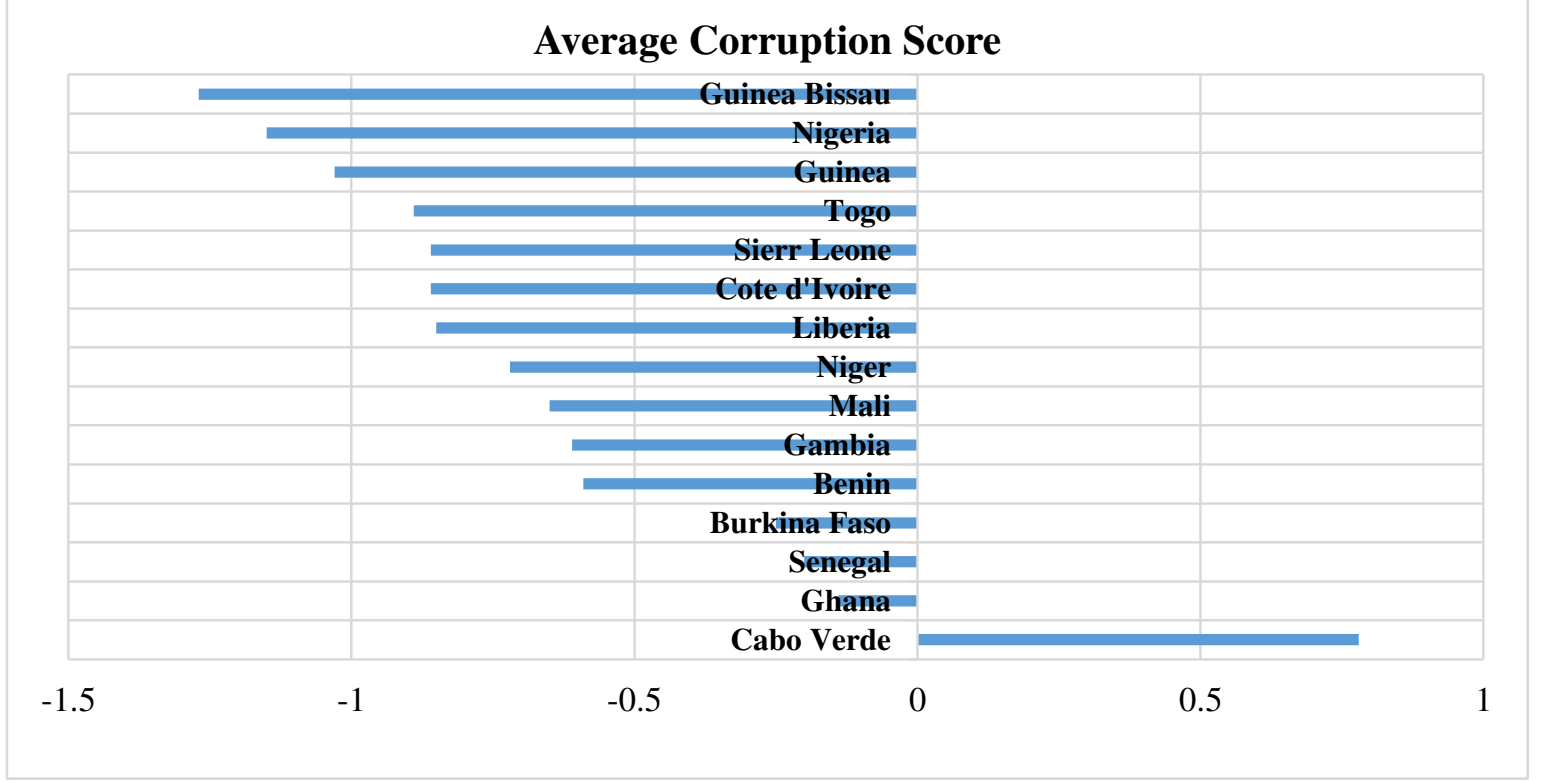

Figure 2: West African Countries Average Corruption Score (2000-2018)

Note: Values are shown on a scale of -2.5 (most corrupt)to +2.5 (least corrupt).

Source: Authors' computation using data from the World Bank’s World Governance Indicator (2019).

\section{Methodology}

\section{Theoretical Framework}

An extended version of a model developed by Kaufman and Wei (2000) is used as the underpinning theoretical framework for the paper. In the original framework, the existence of regulatory burdens or red-tape such as tax or delay in getting permits or licenses experienced by a foreign investment firm might be lowered by paying bribes. In the study, Kaufman and Wei (2000) developed a simple Stackelberg model between a corrupt public official and a firm. Kaufman and Wei (2000) presented the problem faced by the firm in the equation below;

${ }^{5}$ Petty, bureaucratic, grand and political corruption 


$$
e_{i}=h_{i}-s\left(b_{i}\right)
$$

Where: $e_{i}$ is the effective harassment ${ }^{6}$; is nominal harassment ${ }^{7} ; b_{i}$ is the amount of bribe paid by the firm, and $s\left(b_{i}\right)$ is a function that describes how the payment of bribe help to reduce effective harassment. The function is assumed to be twice differentiable and concave $\left(s_{b}>0\right.$ and $\left.s_{b b}<0\right)$. If the nominal harassment, $h_{i}$, is held constant, then the linear relationship between bribery and effective harassment is negative. The implication is that the more the bribe paid by the firm the lower the effective red tape, even though paying bribes has a decreasing return function.

For simplicity, it is assumed that the pre-bribe profit ${ }^{8}, \pi_{i}$, is known. Hence, the objective of the firm now is to maximize after-bribe profit, $\pi_{i}^{*}$, given as:

$\pi_{i}^{*}=w\left(e_{i}\right) \pi_{i}-b_{i}$

Where: $w$ is a function of effective harassment and a product of pre-bribe profit. And to maximize the after-bribe profit, we take the first-order condition (FOC):

$\operatorname{FOC}^{9}\left(\frac{\partial \pi_{i}^{*}}{\partial b_{i}}\right): \quad-w_{e}\left(h_{i}, b_{i}\right) s_{b}\left(b_{i}\right) \pi_{i}=1$

The first-order condition result shows an implicit function that relates to the optimal level of bribe firm $i$ would pay and the nominal harassment rate. But for the maximization condition to be satisfied, the second-derivative must be negative, and this was determined (see Appendix 1).

Totally differentiating the first-order condition, equation (3), yields the optimal bribery schedule, $b_{i}=B\left(h_{i}\right)$ :

$$
\begin{aligned}
& -\left\{\frac{\partial w_{e}}{\partial e_{i}} \cdot \frac{\partial e_{i}}{\partial b_{i}} s_{b} \pi_{i} d b+\frac{\partial w_{e}}{\partial e_{i}} \cdot \frac{\partial e_{i}}{\partial h_{i}} s_{b} \pi_{i} d h+w_{e} s_{b b} \pi_{i} d b\right\}=0 \\
& \left(w_{e e} s_{b}^{2}+w_{e} s_{b b}\right) d b-w_{e e} s_{b} d h=0
\end{aligned}
$$

From (4), we can solve for $\frac{d b}{d h}$;

$$
\frac{d b}{d h}=\frac{w_{e e} s_{b}}{w_{e e} s_{b}^{2}-w_{e} s_{b b}}>0
$$

From (6), the bribery schedule is upward sloping implying that the higher the nominal harassment the more bribe the firm find optimal to give. This is very likely from the firm's perspective because the more the harassment, the more the firm would pay. Similarly, from the public official's perspective, if he wants more bribe, he would harass more.

Without loss of context, an extension to Kaufman and Wei (2000) model is made to incorporate FDI. Similar to Ardiyanto (2012), FDI can be introduced as a function of after-bribe profit, $\pi_{i}^{*}$;

$F D I_{i}=f\left\{\pi_{i}^{*}\left(b_{i}\right)\right\}$

The relationship between FDI and corruption (measured by bribes) can be deduced by chain rule as follows:

$$
\frac{\partial F D I_{i}}{\partial b_{i}}=\frac{\partial F D I_{i}}{\partial \pi_{i}^{*}} \cdot \frac{\partial \pi_{i}^{*}}{\partial b_{i}}
$$

From equation (8), analysis of the effect of corruption on FDI, from the viewpoint of the GHH and $\mathrm{HHH}$, can be done. For the GHH, $\frac{\partial \pi_{i}^{*}}{\partial b_{i}}<0$, because bribes are expected to decrease after-bribe profit. Whereas $\frac{\partial F D I_{i}}{\partial \pi_{i}^{*}}>0$, since the

\footnotetext{
${ }^{6}$ Defined as the red-tape faced by the firm after paying the bribe.

${ }^{7}$ Defined as the harassment imposed by the public official on the firm before any bribe is paid. It can be, for example, the number of days it takes a firm to get a permit.

${ }^{8}$ The profit that the firm would have attained without any harassment.

${ }^{9}$ See Appendix 1 for derivation.
} 
motivation for FDI is positively correlated with after-bribe profit for the firm. Hence, the overall effect would be the case where FDI is discouraged by corruption, $\frac{\partial F D I_{i}}{\partial b_{i}}<0$. Conclusively, a country with high-level corruption attracts less FDI.

For the case of the $\mathrm{HHH}$, the analysis start with the pre-bribe profit $\left(\pi_{i}\right)$ which is the difference between a firm's revenue and cost. In line with the calculation of economics profit, cost is not only considered in its explicit form, but also in its implicit form, like the time it takes a firm to get a permit. Putting it into perspective, imagine a firm that has a container to clear for its production in a corrupt country. The clearance process at customs can take weeks for firms, and the longer the time, the higher the cost incurred by the firm due to storage cost at the port. But beyond that, if the firm's production hinges on the inputs in the container stuck at the port, then the firm would be technically losing revenue. In this case, corruption in the form of bribery can be a useful instrument that can substitute for a weak regulatory environment. Thus, $\frac{\partial \pi_{i}^{*}}{\partial b_{i}}>0$, because corruption in the form of bribery will have a beneficial effect on after-bribe profit, and $\frac{\partial F D I_{i}}{\partial \pi_{i}^{*}}>0$ since the desire to engage in FDI is positively correlated with after-bribe profit. The total effect, in the end, will be $\frac{\partial F D I_{i}}{\partial b_{i}}>0$, implying that the higher the level of corruption in a country, the more the FDI it attracts.

\section{Empirical Model Specification}

Following the extended theoretical framework, and in line with the OLI framework the empirical model is constructed in a linear form as;

$$
\begin{gathered}
F D I_{i t}=\gamma_{0}+\gamma_{1} C_{C O R R_{i t}}+\gamma_{2} G D P P C_{i t}+\gamma_{3} I N F_{i t}+\gamma_{4} N R_{i t}+\gamma_{5} T O P_{i t}+\gamma_{6} P I_{i t} \\
+\varepsilon_{i t}
\end{gathered}
$$

where: FDI is Foreign Direct Investment Inflows, CORR is Corruption, GDPPC is Gross Domestic Product Per Capita, INF is Inflation, NR is Natural Resources, TOP is Trade Openness and PI is Political Instability. $\gamma_{0}, \gamma_{i}$ and $\varepsilon_{i t}$ denote the intercept, parameters to be estimated and the disturbance term respectively. The variables employed conforms to the OLI framework that argues the movement of FDI is mainly influenced by a combination of factors including the market, political, policy and institutional factors. All the variables are expressed in levels except FDI, GDPPC and INF which are expressed in natural logs.

For this study, Net Foreign Direct Investment inflow per capita was used as a proxy measure for FDI. Corruption (CORR) is measured using the control of corruption variable from the World Governance Indicators (WGI), with a scale of -2.5 (most corrupt) to 2.5 (least corrupt). However, for ease of interpretation and in line with Luu et al. (2019), the values were rescaled using the formula: $\operatorname{CORR}=\left(2.5-C O C^{*}\right) \times 2$, where: CORR is the value created for the new scale and $C O C^{*}$ is the control of corruption value on the original scale. The new scale runs from o (least corrupt) to 10 (most corrupt). Generally, corruption inhibits FDI inflows because of the additional cost it creates for investors (CuervoCazurra, 2008)and therefore expected to be negatively signed.

Gross domestic product per capita (GDPPC) is used as a proxy measurement for market size. A large market size provides multinational corporations (MNCs) an opportunity for more revenue generation, profit maximization and the realization of economies of scale (Tsikata, 2005). Hence, the larger the market size, the more the inflow of FDI. Thus, this variable is expected to carry a positive sign.

Trade Openness (TOP), defined as the sum of import and export as a percentage of GDP, measures how open a country's economy is to the rest of the world (Luu et al., 2019). The more open a country's economy, the likelier it is to adopt favourable economic policies that can be appealing and safer for foreign investors (Quazi et al., 2014). Hence, its sign is expected to be positive.

A country's natural resource is a major factor that influences natural resource-seeking FDI (Dunning, 2000; Asiedu, 2006; Anyanwu, 2011). Therefore, the availability of natural resources can be a good conduit for attracting FDI. Total Natural Resource Rent as a percentage of GDP was used as a proxy measure for a country's Natural Resource (NR) endowment, and it is expected to carry a positive sign.

Inflation (INF), defined as the consumer price index, is used as macroeconomic stability measure (Asiedu, 2006). High levels of inflation rate affect society negatively by eroding the purchasing power of consumers, leading to a fall in demand for goods and services and subsequently the profits of businesses (Sayek, 2009). Foreign investors would desist from investing in such countries, INF is thus expected to be negatively signed. 
The World Governance Indicator's (WGI) political stability and absence of violence or terrorism scale is used to measure Political Instability (PI). Like the corruption variable, PI is also rescaled using the same formula ${ }^{10}$. When the occurrence is frequent, PI tends to intensify concerns over the safety of investors' assets (Tsikata, 2005), such that investors will find such locations unattractive for FDI inflows. Therefore, it is expected that the sign of PI is negative.

\section{Estimation Techniques}

To account for slope heterogeneity and cross-sectional dependence, the study employed the Panel Autoregressive Distributive Lag (ARDL) Model. This technique performs better in a macro panel study (Smith and Feurtes, 2016; Chen, 2018). Unlike the panel ARDL model, standard panel estimators tends to ignore some of the potential issues that come along with large $\mathrm{T}$ panels namely: heterogeneity of slope, non-stationarity and Cross-Section Dependence (CSD) because they assume slope homogeneity among cross-section units (Eberhardt, 2011). As such, standard panel estimators might not be idle in similar studies. It is in this spirit that, the panel ARDL model is adopted for this study. The model is a dynamic heterogeneous model developed by Pesaran et al., (1999). It has the advantage of allowing for variables to be differenced and lagged at the same time, which helps to mitigate and eliminate any simultaneity bias and endogeneity problem respectively (Clemens et al., 2012). As such, equation (9) is represented in a panel ARDL form as;

$$
\begin{aligned}
F D I_{i t}=\eta_{i}+\sum_{l=1}^{p} & \delta_{i l} F D I_{i, t-l}+\sum_{l=0}^{q} \lambda_{1 l} \operatorname{CORR}_{i, t-l}+\sum_{l=0}^{q} \lambda_{2 l} G D P P C_{i, t-l}+\sum_{l=0}^{q} \lambda_{3 l} I N F_{i, t-l}+\sum_{l=0}^{q} \lambda_{4 l} N R_{i, t-l}+\sum_{l=0}^{q} \lambda_{5 l} T O P_{i, t-l} \\
& +\sum_{l=0}^{q} \lambda_{6 l} P I_{i, t-l}+v_{i t}
\end{aligned}
$$

Where: $p$ and $q$ are lags of the dependent variable and independent variable respectively; $\delta_{i l}$, the coefficient of the lagged dependent variable, are scalars; $\lambda_{i l}$ are $k \times 1$ coefficient vectors; $\eta_{i}$ is the specific cross-section unit effect (in our case country); and $v_{i t}$ is the random error term assumed to be independently distributed with mean 0 , variances $\sigma_{i}^{2}>0$ and finite fourth-order moment.

To establish the equation that reflects the error correction term which highlights the speed of adjustment term and long-run relation in a linear form, equation (10) is re-parameterize to become;

$$
\begin{aligned}
\Delta F D I_{i t}=\eta_{i}+\theta_{i} & \left(F D I_{i, t-1}-\gamma_{0}-\gamma_{1} \operatorname{CORR}_{i t}-\gamma_{2} G D P P C_{i t}-\gamma_{3} I N F_{i t}-\gamma_{4} N R_{i t}-\gamma_{5} T O P_{i t}-\gamma_{6} P I_{i t}\right) \\
& +\sum_{l=1}^{q} \delta_{i l}^{\prime} \Delta F D I_{i, t-l}+\sum_{l=0}^{q} \lambda_{2 l}^{\prime} \Delta C O R R_{i, t-l}+\sum_{l=0}^{q} \lambda_{2 l}^{\prime} \Delta G D P P C_{i, t-l}+\sum_{l=0}^{q} \lambda_{3 l}^{\prime} \Delta I N F_{i, t-l}+\sum_{l=0}^{q} \lambda_{4 l}^{\prime} \Delta N R_{i, t-l} \\
& +\sum_{l=0}^{q} \lambda_{5 l}^{\prime} T O P_{i, t-l}+\sum_{l=0}^{q} \lambda_{6 l}^{\prime} \Delta P I_{i, t-l} \\
& +v_{i t}
\end{aligned}
$$

To establish the threshold of corruption, equation (11) is expressed in a non-linear form as;

${ }^{10} P I=\left(2.5-P S^{*}\right) \times 2$, where: PI is political instability and $P S^{*}$ is the political stability and absence of violence variable. it is rescaled from -2.5 (least stable) to 2.5 (most stable), to o (most stable) to 10 (least stable). Therefore, the closer a value is to 0 , the less politically unstable a country is and vice-versa. 


$$
\begin{aligned}
\Delta F D I_{i t}=\eta_{i}+\theta_{i} & \left(F D I_{i, t-1}-\gamma_{0}-\gamma_{1} \operatorname{CORR}_{i t}-\gamma_{2} \operatorname{CORR}_{i t}^{2}-\gamma_{3} G D P P C_{i t}-\gamma_{4} I N F_{i t}-\gamma_{5} N R_{i t}-\gamma_{6} T^{q} P_{i t}-\gamma_{7} P_{i t}\right) \\
& +\sum_{l=1}^{q} \delta_{i l}^{\prime} \Delta F D I_{i, t-l}+\sum_{l=0}^{q} \lambda_{2 l}^{\prime} \Delta C O R R_{i, t-l}+\sum_{l=0}^{q} \lambda_{2 i}^{\prime} \Delta C O R R_{i, t-l}^{2} \sum_{l=0}^{q} \lambda_{3 l}^{\prime} \Delta G D P P C_{i, t-l}+\sum_{l=0}^{q} \lambda_{4 l}^{\prime} \Delta I N F_{i, t-l} \\
& +\sum_{l=0}^{q} \lambda_{5 l}^{\prime} \Delta N R_{i, t-l}+\sum_{l=0}^{q} \lambda_{6 l}^{\prime} T O P_{i, t-l}+\sum_{l=0}^{q} \lambda_{7 l}^{\prime} \Delta P I_{i, t-l}+v_{i t}
\end{aligned}
$$

Where: $\theta_{i}=-\left(1-\sum_{l=1}^{p} \delta_{i l}\right)$, measures the reaction level of the system to any shock, referred to as the speed of adjustment. It is expected to be negative (below negative 2 ) and statistically significant. $\gamma_{i, \text { for } i=1,2, \ldots, 7}$, the vector of longrun coefficients; and the terms in the bracket reflects the regression for the long-run relationship between the dependent variable and independent variables. Equation (12) is used to determine the threshold level for corruption. In line with Abotsi and Iyavarakul (2015) and Oktay (2017), the study expects $\gamma_{1}>0$ and $\gamma_{2}<0$, and must be statistically significant. Implying that corruption at some initial level has a positive influence on FDI but afterwards, doubling or increase in the level of corruption will change the influence to negative ${ }^{11}$.

The re-parameterized panel ARDL model is used to estimate both the Mean Group (MG) estimator and the Pooled Mean Group (PMG) estimator, for which the Hausman (1978) test is applied to decide on the appropriate estimator. Both estimators are likelihood ratio tests which are appropriate for heterogeneous panel studies in which $\mathrm{T}$ is greater than $\mathrm{N}$ (Smith and Fuertes, 2016).

The MG estimator as developed by Pesaran and Smith (1995) involves estimating separate regressions for each group and averaging the slopes over groups. This approach allows for coefficients to differ across countries for both the short-run and long-run, thus imposing no restrictions on the coefficients. The test performs better with large $\mathrm{N}$ and large $\mathrm{T}$ panels, but it's unlikely to be a good estimator when $\mathrm{T}$ or $\mathrm{N}$ is small (Pesaran et al., 1999). Alternatively, the PMG estimator, proposed by Pesaran et al., (1999), involves both pooling and averaging. The PMG estimator has the advantage of being applied to models in which variables are integrated of different orders. However, the PMG will be inefficient if slope heterogeneity holds in the long run. Nevertheless, PMG is quite appealing when studying small sets of similar countries (Onuoha et al., 2018).

\section{Data}

The study utilized an unbalanced panel data for 15 countries in West Africa over the period 1999-2018. Data for the study were sourced from the World Bank online database (2019) -World Development Indicators (WDI, 2019) and World Governance Indicators (WGI, 2019), and the United Nations Conference on Trade and Development (UNCTAD) online data (2019).

\section{Results}

To appreciate the preliminary relationship between corruption and FDI, a scatter plot of the average values of each country on FDI per capita and corruption was conducted (Figure 5.1). In general, the plot shows an inverse relationship between corruption and FDI per capita. For example, Cape Verde recorded the least average corruption score (around 3.5) and receives the highest average FDI per capita. Conversely, Guinea Bissau registered the highest corruption score and received the lowest average per capita FDI. Overall, most of the countries that recorded low FDI per capita on average score high on the corruption scale on average.

\footnotetext{
${ }^{11}$ Thus, exhibiting decreasing returns for FDI inflows.
} 


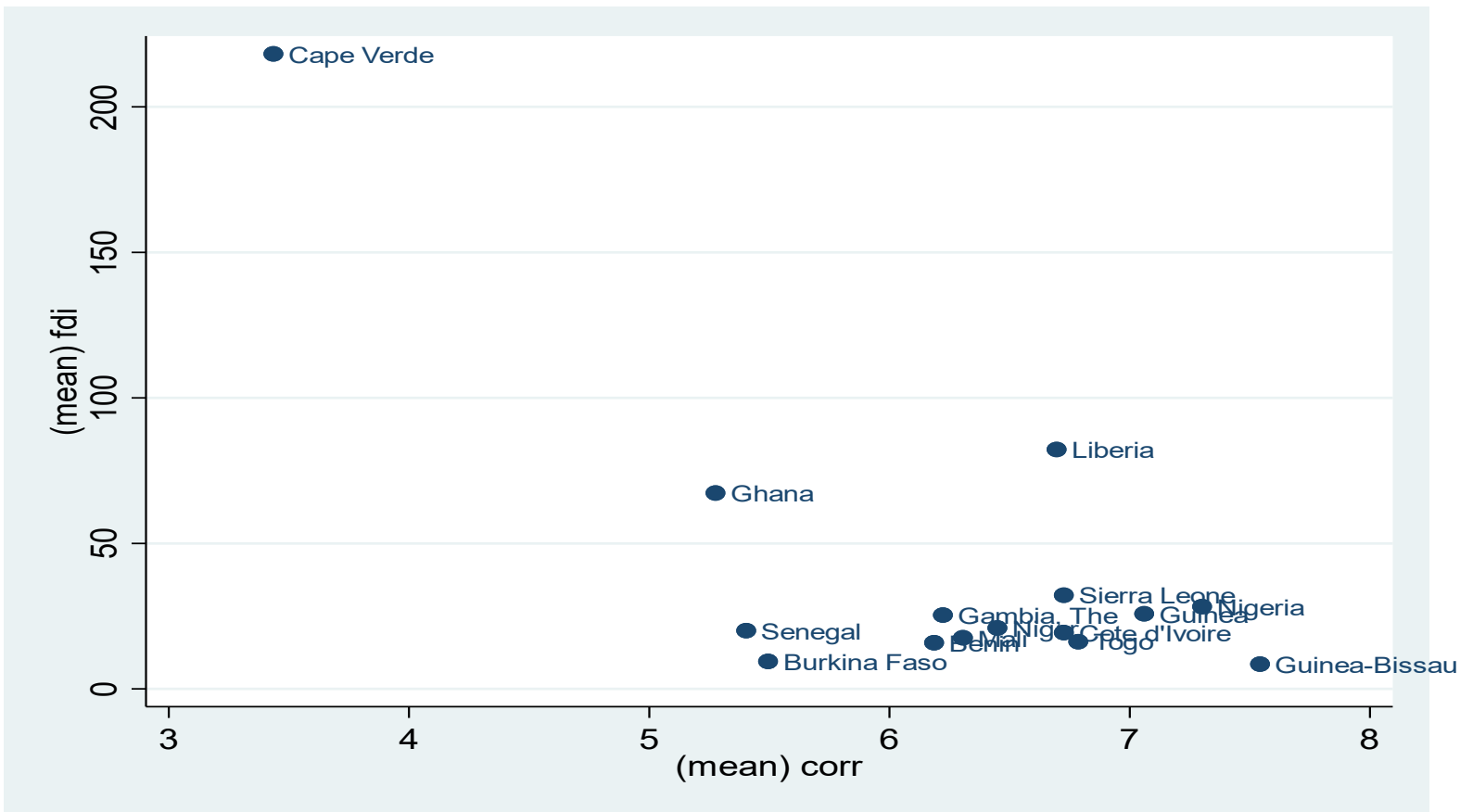

Figure 3. 1: Average FDI per capita (unlogged) and average corruption (1999-2018)

Source: Stata 15 output

Cross Section Dependence (CSD) Test

The Pesaran (2004) CSD test was used in the study. Unlike other tests ${ }^{12}$, it can be applied on pre (or post)-estimation ${ }^{13}$, and has the advantage of being applied to a variety of panel models (Baltagi, 2005). It is based on the average pair-wise correlation coefficients of the Ordinary Least Squares (OLS) residuals from individual regressions in the panel and is robust to structural breaks in the slope coefficients and (or) error variances with the correct size for small samples and satisfactory power (Pesaran, 2004).

Nonetheless, for this paper, the post-estimation ${ }^{14}$ test was conducted, since tests to validate the reliability of a regression result is conducted on the residuals (Anderson et al., 2020). Results from Table 5.2 show that there is no presence of CSD in both models, Model 1 (Linear model) and Model 2 (Non-linear model).

Table 1. Pesaran (2004) Cross-Section Dependence test on the residuals Results

\begin{tabular}{lcc}
\hline & Model 1 & Model 2 \\
\hline Cross-section dependence test & 0.636 & 0.625 \\
& $(0.525)$ & $(0.532)$
\end{tabular}

Note: values in parenthesis represent P-Value and values, not in parenthesis represents test value. Also, no asterisks imply no significance. $\mathrm{H}_{0}$ : Cross-section independence.

Source: Authors' computation using output from Stata

\section{The Panel Unit Root test}

The Im-Peasran-Shin (2003) panel unit root test was adopted based on the outcome of the CSD test. The test, unlike the others ${ }^{15}$, have the advantage of being applied to an unbalanced panel. The test is based on the average of individual

12 Breusch and Pagan (1980) Langrage Multiplier test and Pesaran et al. (2008) Langrange Multiplier adjusted tests.

${ }_{13}$ The pre-estimation is done on the series while the post-estimation is done on the residuals.

${ }_{14}$ It was conducted at the back of the fixed-effect model estimation. 
unit root statistics and can be adopted in dynamic heterogeneous panels. The test allows for serial correlation in residuals and heterogeneity dynamics and error variances across groups (Barbieri, 2006).

Table 2. Im-Pesaran-Shin (2003) Panel Unit Root Test Results

\begin{tabular}{lcc}
\hline Variable & Demean Without trend & Demean With trend \\
\hline LOGFDI & $\mathrm{I}(0)$ & $\mathrm{I}(0)$ \\
CORR & $\mathrm{I}(0)$ & $\mathrm{I}(1)$ \\
LOGGDPPC & $\mathrm{I}(0)$ & $\mathrm{I}(1)$ \\
LOGINF & $\mathrm{I}(1)$ & $\mathrm{I}(1)$ \\
NR & $\mathrm{I}(0)$ & $\mathrm{I}(0)$ \\
TOP & $\mathrm{I}(1)$ & $\mathrm{I}(1)$ \\
PI & $\mathrm{I}(0)$ & $\mathrm{I}(0)$ \\
CORRSQ & $\mathrm{I}(0)$ & $\mathrm{I}(1)$ \\
\hline
\end{tabular}

Note: Demean was used because it helps to mitigate the problem of cross-sectional dependence (Levin and Lu, 1992). Source: Authors' computation using output from Stata.

The results, as presented in Table 5.3, shows that the variables were stationary with and without trend, albeit some at level and others after first differencing. The variables LOGFDI, NR and PI were stationary at level with and without trend, while TOP and LOGINF were stationary after first difference in both cases, leaving CORR and LOGGDPPC with mixed results for the case of trend and no trend.

\section{The Panel Cointegration Test Results}

The Pedroni (1999, 2004) cointegration test was utilized for this study since it is the only cointegration test ${ }^{16}$ that can be used for unbalanced panels. The test is a residual-based test designed for the heterogeneous panel. Pedroni (1999, 2004) proposed seven residual-based test statistic, of which, four are based on pooling along the within dimension, while the other three are pooled along the between dimension. The test was conducted to check for a long-run relationship, and it was tested on the null hypothesis of no cointegration. The simple decision rule is that at least four of the seven residualbased test statistic must be significant to reject the null. Table 5.4 present the results for the cointegration test. From the results, the study rejects the null of no cointegration for both models.

Table 3. Pedroni's (1999, 2004) Cointegration Test Results

\section{Model $1 \quad$ Model 2}

\begin{tabular}{|c|c|c|}
\hline \multicolumn{3}{|c|}{ Panel: } \\
\hline V & $-4.86 * * *(0.000)$ & $-5.53 * * *(0.000)$ \\
\hline Rho & $3.56^{* * *}(0.000)$ & $4.26 * * *(0.000)$ \\
\hline
\end{tabular}

${ }_{15}$ Like Levin and Lin (1992), Maddala and Wu (1999), Hadri (2000), etc (see Barbieri, 2005; Baltagi, 2005; Eberhardt, $2011)$.

${ }^{16}$ Others include, Westerlund (2007), Kao (1999), Gengenbach, Urbain and Westerlund (2009) and McCoskey and Kao (1998). 

Group:

$\begin{array}{crc}\text { Rho } & 5.14^{* * *}(0.000) & 5.89 * * *(0.000) \\ \text { T } & -4.57^{* * *}(0.000) & -4.21 * * *(0.000) \\ \text { ADF } & -4.10^{* * *}(0.000) & -3.13^{* * *}(0.001)\end{array}$

Note: ADF is Augmented Dickey-Fuller t-statistics; $t$ is Phillip and Perron t-statistics; rho is the modified Phillip and Perron t-statistics, and $\mathrm{v}$ is the modified variance ratio statistics. The Null hypothesis is no cointegration, while the alternative is that all panels are cointegrated. The asterisks, ***,** and $*$, represents the level of significance at the $1 \%$, $5 \%$ and $10 \%$ respectively. Values in parenthesis are p-values.

Source: Authors' computation using Stata 15 output.

\section{Pooled Mean Group (PMG) Results}

Based on the Hausman (1978) test result, the PMG was deemed appropriate for our analysis. Table 5.5 present the long and short-run panel estimate results for the linear and non-linear model represented by Model 1 and Model 2 respectively. The results from Table 5.5 revealed that the adjustment terms (ECT) in both models were highly significant with the expected sign and within an acceptable region. The results suggest that any short-run disequilibrium in the model can be corrected at the 57 and 60\% adjustment speed annually for Model 1 and Model 2 respectively. These results further support the existence of a long-run relationship in both models. All the long-run variables were significant under Model 1 except Trade Openness (TOP) and Political Instability (PI), while for Model 2, only TOP was insignificant. Furthermore, all the significant variables carried their expected signs. However, except the intercept and ECT, no variable was significant for the short-run panel estimates. The discussion of the Models proceed as follows:

Model 1

The results under Model 1 investigates the effect of corruption on FDI inflows to West Africa. The result from the model revealed that ceteris paribus, a one-point increase in the level of corruption (CORR) can reduce per capita FDI inflows to West Africa by 15 percentage point, implying that corruption discourages the movement of FDI into the subregion in the long-run. The finding is in line with the GHH, consistent with the study's expectations, and corroborate the findings of Fahad and Ahmad (2016) and Luu et al. (2019). Therefore, in general, locations with a high level of corruption increases the risks and uncertainty associated with investment - a dislikeable feature for any foreign investor - due to its illegality and secrecy (Shleifer and Vishny, 1993). As a result, foreign investors might desist from investing in such locations, because corruption acts as an additional unofficial tax burden that increases the cost of doing business.

The results also showed that ceteris paribus, a 1 percentage point increase in Gross Domestic Product Per Capita (GDPPC) can raise the inflow of FDI per capita to West Africa by 0.91 percentage point in the long-run. The finding is in agreement with the theory of market-seeking FDI or horizontal FDI and is in line with findings from Quazi et al. (2014). Generally, the GDPPC is used to reflect the purchasing power of the average consumers, thus, foreign investors looking to expand their market find such locations appealing.

Also, it was observed from the result that a 1 percentage point increase in the level of inflation (INF) can lead to a reduction in the inflow of FDI per capita to West Africa by 0.67 percentage points in the long-run, all else constant. The result implies that the higher the level of inflation the lower the inflow of FDI. Thus, investing in a country with less degree of market uncertainty is preferable to foreign investors because it tends to be more stable economically and provide lower risk for investment. The findings support previous studies by Asiedu (2013), Abotsi and Iyavarakul (2015), and Gossel (2018). 
Aside from that, the result also showed Natural Resources (NR) to attract FDI inflows to West Africa. The result shows that a 1 percentage point increase in NR can raise the inflow of FDI per capita to West Africa by 0.02 percentage point, ceteris paribus, in the long-run. The finding is consistent with the theory of natural resource-seeking FDI. Therefore, natural resources, especially oil, can attract FDI inflows (Anyanwu and Yameogo, 2015). As such, the higher the abundance in natural resources, the more likely is the inflow of FDI holding all else equal. However, Trade Openness (TOP) and Political Instability (PI) were found to be insignificant in the long-run. Furthermore, no variable was significant for the short-run panel estimates.

Table 4. PMG Estimation Results

\begin{tabular}{lcc}
\hline & Model 1 & Model 2 \\
\hline CORR & LONG-RUN & $1.413^{* * *}(0.285)$ \\
LOGGDPPC & $-0.154^{* * *}(0.026)$ & $0.803^{* * *}(0.125)$ \\
LOGINF & $0.909^{* * *}(0.112)$ & $-0.612^{* * *}(0.093)$ \\
NR & $-0.665^{* * *}(0.088)$ & $0.014^{*} * *(0.002)$ \\
TOP & $0.0184^{* * *}(0.002)$ & $-0.0001(0.0004)$ \\
PI & $-0.0002(0.001)$ & $-0.060^{* * *}(0.013)$ \\
CORRSQ & $-0.017(0.017)$ & $-0.112^{* * *}(0.021)$ \\
\hline
\end{tabular}

\section{SHORT RUN}

\begin{tabular}{lcc}
\hline ECT & $-0.572^{* * *}(0.111)$ & $-0.595^{* * *}(0.190)$ \\
D.CORR & $0.062(0.103)$ & $0.21(1.639)$ \\
D.LOGGDPPC & $0.344(0.534)$ & $0.644(0.673)$ \\
D.LOGINF & $0.791(1.607)$ & $-0.334(1.541)$ \\
D.NR & $-0.039(0.044)$ & $0.010(0.022)$ \\
D.TOP & $0.006(0.005)$ & $-0.056(0.044)$ \\
D.PI & $-0.046(0.043)$ & $-0.0561(0.044)$ \\
D.CORRSQ & & $-2.147 * *(0.700)$ \\
Cons & $0.705 * * *(0.178)$ & 225 \\
N & 225 & 285.058 \\
Log Likelihood & 265.042 & $-0.049)$ \\
\hline
\end{tabular}

Standard errors in parenthesis. ${ }^{*} \mathrm{p}<0.1,{ }^{* *} \mathrm{p}<0.05,{ }^{* * *} \mathrm{p}<0.01$

Note: The lag-structure of the models was ARDL $(1,0,0, \ldots, 0)$.

Source: Authors' computation using STATA 15 output 
Model 2 answers the study's second objective, which is to determine a threshold level for corruption in West Africa. In line with expectations from equation (12), the coefficient of CORR and CORRSQ (corruption square) under Model 2 were found to be statistically significant with the required signs in the long-run. Thus, indicating that corruption has a positive influence on FDI inflow initially but doubling the level of corruption or making it widespread, will have a negative influence in the end (Abotsi and Iyavarakul 2015; Oktay, 2017).

Having met the pre-conditions, the threshold level was determined by solving the derivative of the dependent variable, per capita FDI inflow (LOGFDI), with respect to the variable of interest, corruption (CORR) (see Appendix 2). The study found the threshold level of corruption to be $6.3^{17}$. The result explains that the inflow of FDI to a country in West Africa could not be discouraged once the level of corruption is below 6.3 but beyond that level, the inflow of FDI would be discouraged. This threshold level is close to the level established by Abotsi and Iyavarakul (2015) ${ }^{18}$ of -0.27 , which translate into 5.54 on the study's rescale. Based on the result, only seven countries had an average score equal or below the threshold level: Cape Verde (3.4), Ghana (5.3), Senegal (5.4), Burkina Faso (5.5), Benin (6.2), Gambia (6.2) and Mali (6.3). The remaining eight countries failed to meet the threshold level with Guinea Bissau averaging the worst score, 7.5. The pre-condition for a corruption threshold level in the short-run panel estimate was met, however, the variables were statistically insignificant.

\section{Conclusion and Recommendations}

In analysing corruption and FDI inflows into West Africa, the study investigated the long and short-run effect of corruption on FDI inflow, as well as to determine the threshold corruption level. The result revealed that corruption has a negative effect on FDI in the long-run, suggesting that corruption act as an obstacle to the inflow FDI in West Africa. The result was found to be consistent with the "grabbing hand" hypothesis. However, in the short-run corruption was found to share a positive association with FDI inflows into the sub-region albeit statistically insignificant. In response to the other objective, a threshold level of corruption was established only for the long-run. It was suggested that corruption levels below the threshold level cannot discourage FDI inflows to West Africa and above that level, corruption can discourage FDI inflows. Also, the market size, macroeconomic condition and natural resources were also found to have an influence on FDI inflows to West Africa in the long-run. Based on the findings, the authors recommend that West African governments direct focus on mechanisms that will strongly discourage people from engaging in corruption by reducing unnecessary delays and ensuring that the consequences are dire. With this, the level of corruption could be reduced and FDI activities will become attractive. Furthermore, governments, particularly in countries that had a score above the threshold level, should intensify efforts to fight corruption and reduce it to at least the threshold level which is just enough for attracting FDI. This can be done by strengthening, and ensuring effective monitoring of public institutions and agents while recognising and providing a reward for honesty.

\section{References}

Abotsi, A.K. and Iyavarakul, T., 2015. Tolerable level of corruption for foreign direct investment in Africa. Contemporary Economics, 9(3), pp. 249-270.

Akonnor, K. T., 2018. The Impact of Foreign Direct Investment (FDI) on Economic Growth: A Comparative Study of East and Central Africa. Doctoral dissertation, University of Ghana.

Anderson A. D., Thomas A. W. and Dennis J. S., 2020. Statistics, Encyclopedia Britannica, Inc.

Andvig, J. C., 2008. Corruption in Sub-Saharan Africa and its sources of evidence. Norwegian Institute of International Affairs (NUPI), Working Paper 744.

Anyanwu, J.C., 2011. Determinants of foreign direct investment inflows to Africa, 1980-2007. African Development Bank Group. pp. 1-32. Anyanwu, J.C. and Yameogo, N.D., 2015. What drives foreign direct investments into West Africa?” An empirical investigation. African Development Review, 27(3), pp.199-215.

Ardiyanto, F., 2012. Foreign direct investment and corruption. Doctoral Dissertation, Colorado State University.

Asiedu, E., 2006. Foreign direct investment in Africa: The role of natural resources, market size, government policy, institutions and political instability. World economy, 29(1), pp.63-77.

Asiedu, E., 2013. Foreign direct investment, natural resources and institutions. International Growth Centre, wp 47.

${ }^{17}$ Equivalent to -0.65 on the original scale.

${ }^{18}$ The threshold by Abosti and Iyavarakul (2016) was done for Africa. 
Ayanwale, A. B., 2007. FDI and economic growth: Evidence from Nigeria. African Economic Research Consortium, Nairobi, AERC Research Paper 165.

Bardhan, P., 1997. Corruption and development: a review of issues. Journal of economic literature, 35(3), pp. 1320-1346.

BBC, 2019a. BP to pay billions for suspicious Senegal gas deal. https://www.bbc.com/news/av/world-africa-48475068/bp-to-paybillions-for-suspicious-senegal-gas-deal (August, 2020).

Bellos, S. and Subasat, T., 2012. Corruption and foreign direct investment: A panel gravity model approach. Bulletin of Economic Research, 64(4), pp. 565-574.

Blundo, G., and Olivier de Sardan, J. P., 2006. Everyday Corruption in West Africa., G. Blundo and JP Olivier de Sardan, JP.

Buckley, P. J., and Casson, M. C., 1976. The future of multinational enterprise. Macmillan, London.

Chakrabarti, A., 2001. The determinants of foreign direct investments: Sensitivity analyses of cross-country regressions. kyklos, 54(1), pp. 89-114.

Chande, K. A., 2014. Africa rising: Corruption and foreign direct investment inflows. CMC Senior Theses Paper 1023. https://scholarship.claremont.edu/cmc_theses/1023

Chêne M., 2010. Overview of corruption and anti-corruption in Sierra Leone. Anti-Corruption Helpdesk, Transparency International, U4 Anti-Corruption Resource Centre.

Clemens, M. A., Radelet, S., Bhavnani, R. R., and Bazzi, S., 2012. Counting chickens when they hatch: Timing and the effects of aid on growth. The Economic Journal, 122(561), 590-617.

Cuervo-Cazurra, A., 2008. Better the devil you don't know: Types of corruption and FDI in transition economies. Journal of International Management, 14(1), pp. 12-27.

Dicken, P., and Lloyd, P. E., 1977. Location in space: A theoretical approach to economic geography. Loanna Cotler, London.

Dunning, J. H., 1995. Reappraising the Eclectic Paradigm in an Age of Alliance Capitalism. Journal of International Business Studies, 26, pp. 461-491.

Dunning, J. H., 1977. Trade, location of economic activity and the MNE: A search for an eclectic approach. The international allocation of economic activit, Palgrave Macmillan, London, pp. 395-418.

Dunning, J. H., 2000. The eclectic paradigm as an envelope for economic and business theories of MNE activity. International business revier, 9(2), pp.163-190.

Eberhardt, M., 2011. September. Panel time-series modeling: New tools for analyzing xt data. In 2011 UK Stata Users Group meeting.

Fahad, A. Y., and Ahmed, M., 2016. The Impact of Corruption on Foreign Direct Investment (FDI) in Post-Conflict Countries: A Panel Causality. Test. Journal of Advanced Social Research, 6(3), pp. 1-12.

Goodspeed, T., Martinez-Vazquez, J., and Zhang, L., 2011. Public policies and FDI location: Differences between developing and developed countries. FinanzArchiv/Public Finance Analysis, pp. 171-191.

Gossel, S. J., 2018. FDI, democracy and corruption in Sub-Saharan Africa. Journal of Policy Modeling, 40(4), pp. 647-662.

Gui-Diby, S. L., and Renard, M. F., 2015. Foreign direct investment inflows and the industrialization of African countries. World Development, 74, pp. 43-57.

Hanson, S., 2009. Corruption in Sub-Saharan Africa, Washington, DC.

Hasan, M., Rahman, M. N., and Iqbal, B. A., 2017. Corruption and FDI inflows: Evidence from India and China. Mediterranean Journal of Social Sciences, 8(4 S1), 173.

Heidhues, F. and Obare, G.A., 2011. Lessons from structural adjustment programmes and their effects in Africa. Quarterly Journal of International Agriculture, 50(892-2016-65193), pp. 55-64.

Hines Jr, J. R., 1995. Forbidden payment: Foreign bribery and American business after 1977, National Bureau of Economic Research, Working Paper 5266.

Hymer, S. H., 1976. International operations of national firms: A study of foreign direct investment. MIT press, USA.

Im, K. S., Pesaran, M. H., and Shin, Y., 2003. Testing for unit roots in heterogeneous panels. Journal of econometrics, 115(1), pp. 53-74.

International Finance Corporation (IFC), 2019. Country Private Sector Diagnostic: Growing Burkina Faso's Private Sector and harnessing it to bolster economic resilience. World Bank Group.

Jalloh, M., 2013. Natural resources endowment and economic growth: The West African Experience. Journal of Natural Resources and Development, 3, pp. 66-84.

Kaufmann, D., and Wei, S. J., 2000. Does 'grease money' speed up the wheels of commerce? IMF Working Paper WP/o0/64.

Lagarde, C., 2017. Addressing corruption with clarity, Speech at the Brookings Institution. https://www.imf.org/en/News/Articles/2017/09/18/sp091817-addressing-corruption-with-clarity (August, 2020).

Lee-Jones K., 2019. Liberia: Overview of corruption and anti-corruption. Anti-Corruption Helpdesk, Transparency International, U4 Anti-Corruption Resource Centre.

Leff, N. H., 1964. Economic development through bureaucratic corruption. American behavioral scientist, 8(3), pp. 8-14.

Lui, F. T., 1985. An equilibrium queuing model of bribery. Journal of political economy, 93(4), pp. 760-781.

Luu, H.N., Nguyen, N.M., Ho, H.H. and Nam, V.H., 2019. The effect of corruption on FDI and its modes of entry. Journal of Financial Economic Policy.

Okafor, G., Piesse, J., and Webster, A., 2017. FDI determinants in least recipient regions: The case of Sub-Saharan Africa and MENA. African Development Review, 29(4), pp. 589-600.

Oktay, K., 2017. Effect of Corruption on FDI in transition economies: evidence from causality analysis. Uluslararası Iktisadi ve Idari Incelemeler Dergisi, (19), pp. 25-42. 
Omankhanlen, A. E., 2011. The effect of exchange rate and inflation on foreign direct investment and its relationship with economic growth in Nigeria. Economics and Applied Informatics, $1,1$.

Omodero, C.O., 2019. Effect of corruption on foreign direct investment inflows in Nigeria. Studia Universitatis Vasile Goldiş, Arad-Seria Ştiinţe Economice, 29(2), pp. 54-66.

Onuoha, F. C., Okonkwo, I. C., Okoro, P., and Okere, K., 2018. The causal relationship between Foreign Direct Investment (FDI) and the macro-economy of selected West African countries: Panel ARDL/Granger Causality Analysis. African Research Review, 12(1), pp.140-163.

Pedroni, P., 1999. Critical values for cointegration tests in heterogeneous panels with multiple regressors. Oxford Bulletin of Economics and statistics, 61(S1), pp. 653-670.

Pedroni, P., 2004. Panel cointegration: asymptotic and finite sample properties of pooled time series tests with an application to the PPP hypothesis. Econometric theory, 20(3), pp. 597-625.

Pesaran, M. H., and Smith, R., 1995. Estimating long-run relationships from dynamic heterogeneous panels. Journal of econometrics, 68(1), pp. 79-113.

Pesaran, M. H., Shin, Y., and Smith, R. P., 1999. Pooled mean group estimation of dynamic heterogeneous panels. Journal of the American Statistical Association, 94(446), pp. 621-634.

Peseran, H., 2004. General Diagnostic Tests for Cross Section Dependence in Panels. University of Cambridge and IZA Bonn, Discussion paper No.1240.

Pring, C., and Vrushi, J., 2019. Global Corruption Barometer: Africa 2019, Transparency International.

Quazi, R., Vemuri, V., and Soliman, M., 2014. Impact of corruption on foreign direct investment in Africa. International Business Research, 7(4), 1.

Rahman K., 2019. The Gambia: Overview of corruption and anti-corruption. Transparency International Anti-Corruption. Helpdesk Answer.

Sayek, S., 2009. Foreign direct investment and inflation. Southern Economic Journal, 76(2), pp. 419-443.

Scott, W. R., 2001. Institutions and organizations (2nd [thoroughly rev. and expanded] ed.), Thousand Oaks, CA.[etc.]: Sage.

Shipley T., 2018a. The Role of civil society in fighting corruption in Cote d'Ivoire. Anti-Corruption Helpdesk, Transparency International, U4 Anti-Corruption Resource Centre.

Shipley T., 2018b. Country profile: Senegal Overview of corruption and anti-corruption, Transparency International, U4 Helpdesk Answer 2018:14. U4 Anti-Corruption Resource Centre.

Shleifer, A., and Vishny, R. W., 1993. Corruption. The quarterly journal of economics, 108(3), pp. 599-617.

Smith, R. P. and Fuertes, A. M., 2016. Panel Time Series. Cemmap course notes.

Teixeira, A. A., and Guimarães, L., 2015. Corruption and FDI: Does the Use of Distinct Proxies for Corruption Matter? Journal of African Business. 16(1-2), pp. 159-179.

Tsikata, D., 2005. Determinants of Foreign Direct Investment in Sub-Saharan Africa. MPhil dissertation, University of Ghana.

Udenze, O., 2014. The effect of corruption on foreign direct investments in developing countries. The Park Place Economist: Vol. 22, http://digitalcommons.iwu.edu/parkplace/vol22/iss 1/17 (July, 2020).

United Nations Conference on Trade and Development, 2010. Investing in a Low-Carbon Economy. World Investment Report, New York and Geneva: United Nations.

United Nations Conference on Trade and Development, 2019. Special economic zones, World Investment Report, New York: United Nations.

United Nations Conference on Trade and Development, 2019. UNCTAD Statistics, https://unctadstat.unctad.org/wds/ReportFolders/reportFolders.aspx?sCS_ChosenLang=en (July, 2020).

Vernon, R., 1966. International trade and international investment in the product cycle. Quarterly journal of economics, 80(2), pp. $190-207$. Wei, S. J., 1997. Why is corruption so much more taxing than tax? Arbitrariness kills, (No. w6255).

Wei, S. J., 2000. How taxing is corruption on international investors?” Review of economics and statistics, 82(1), pp. 1-11.

World Development Indicators databank, 2019. The World Bank Databk, https://databank.worldbank.org/indicator/NY.GDP.MKTP.KD.ZG/1ff4a498/Popular-Indicators (July, 2020).

World Governance Indicators databank. 2019. The World Bank Databank. https://databank.worldbank.org/source/worldwidegovernance-indicators (July, 2020)

This is an Open Access article distributed under the terms of the Creative Commons Attribution Licence

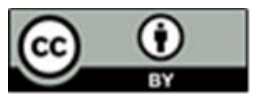


Appendix 1: Derivation of the Second-order condition

Recall and re-writing equation (3) gives;

$$
-w_{e}\left(h_{i}, b_{i}\right) s_{b}\left(b_{i}\right)=\frac{1}{\pi_{i}}
$$

Taking second-order condition on the above,

$\frac{\partial^{2} \pi_{i}^{*}}{\partial b_{i}^{2}}=-\left\{w_{e e}\left(-s_{b}\right) s_{b}+w_{e}\left(h_{i}, b_{i}\right) s_{b b}\left(b_{i}\right)\right\}=-\left\{w_{e e}\left(-s_{b}^{2}\right)+w_{e}\left(h_{i}, b_{i}\right) s_{b b}\left(b_{i}\right)\right\}<0$

Where: $w_{e}<0, w_{e e}<0, s_{b}>0$ and $s_{b b}<0$; thus, satisfying the maximization condition.

Appendix 2: Calculation of the Threshold Level of Corruption for West Africa

$$
\frac{\partial L O G F D I_{i t}}{\partial C O C_{i t}}=1.413-0.224 \times C O C_{i t}=0
$$

Solving the above equation gives:

$$
\operatorname{COC}_{i t}=\frac{1.413}{0.224}=6.308
$$

\begin{tabular}{|c|c|c|c|}
\hline Variable & Description & Source & Expected sign \\
\hline FDI & US dollars at current prices per capita & UNCTAD (2019) & \\
\hline CORR & $\begin{array}{l}\text { Perception index measured on a scale of - } \\
2.5 \text { to } 2.5 \text { (later rescaled) }\end{array}$ & World Bank’s WGI (2019) & Negative \\
\hline GDPPC & Current US $\$$ & World Bank’s WDI (2019) & Positive \\
\hline INF & $\begin{array}{l}\text { Consumer price index with } 2010 \text { as the } \\
\text { base year }\end{array}$ & UNCTAD (2019) & Negative \\
\hline \multirow[t]{2}{*}{ TOP } & (Export + Import $)$ & \multirow[t]{2}{*}{ World Bank’s WDI (2019) } & \multirow[t]{2}{*}{ Positive } \\
\hline & $(G D P$ & & \\
\hline NR & $\begin{array}{c}\text { Total natural resources rent as a } \\
\text { percentage of } G D P\end{array}$ & World Bank’s WDI (2019) & Positive \\
\hline PI & $\begin{array}{l}\text { Perception index measured on a scale of - } \\
2.5 \text { to } 2.5 \text { (later rescaled) }\end{array}$ & World Bank’s WGI (2019) & Negative \\
\hline \multicolumn{4}{|c|}{ COUNTRIES } \\
\hline
\end{tabular}

Appendix 3: Summary of Variable Description and the 15 countries considered in the study.

Appendix 4: Descriptive Statistics 


\begin{tabular}{llllll}
\hline Variable & Obs. & Mean & Std. Dev. & Min & Max \\
\hline LOGFDI & 300 & 1.57 & 0.347 & -0.39 & 2.64 \\
CORR & 270 & 6.24 & 1.047 & 3.1 & 8.12 \\
LOGGDPPC & 299 & 2.825 & 0.341 & 0 & 3.57 \\
LOGINF & 300 & 1.95 & 0.18 & 1.23 & 2.41 \\
NR & 284 & 11.105 & 7.667 & .37 & 53.63 \\
TOP & 299 & 69.013 & 34.734 & 20.72 & 311.35 \\
PI & 270 & 6.03 & 1.63 & 2.56 & 9.8 \\
\hline
\end{tabular}

Appendix 5: Matrix of Correlations

\begin{tabular}{llllllll}
\hline Variables & $(\mathbf{1})$ & $(\mathbf{2})$ & $(\mathbf{3})$ & $(\mathbf{4})$ & $(\mathbf{5})$ & $(\mathbf{6})$ & $(\mathbf{7})$ \\
\hline (1) LOGFDI & 1.000 & & & & & & \\
(2) CORR & -0.482 & 1.000 & & & & & \\
(3) LOGGDPPC & 0.580 & -0.447 & 1.000 & & & & \\
(4) LOGINF & 0.212 & -0.052 & 0.412 & 1.000 & & & \\
(5) NR & 0.040 & 0.484 & -0.281 & 0.091 & 1.000 & & \\
(6) TOP & 0.344 & -0.146 & 0.027 & -0.035 & 0.251 & 1.000 & \\
(7) PI & -0.208 & 0.647 & -0.076 & -0.019 & 0.394 & 0.005 & 1.000 \\
\hline
\end{tabular}

Appendix 6: Mean Group ARDL Results for Both the Short and Long-Run

\begin{tabular}{lll}
\multicolumn{3}{l}{ Appendix 6: Mean Group ARDL Results for Both the Short and Long-Run } \\
\hline LONG-RUN & \multicolumn{1}{l}{ Model 1 } \\
\hline CORR & $0.175(0.380)$ & $77.26(81.28)$ \\
LOGGDPPC & $-3.647(2.062)$ & $-1.062(1.332)$ \\
LOGINF & $4.252(2.580)$ & $3.260(2.788)$ \\
NR & $0.008(0.041)$ & $0.143(0.146)$ \\
TOP & $-0.034(0.029)$ & $0.029(0.036)$ \\
PI & $-0.195(0.180)$ & $0.0041(0.207)$ \\
CORRSQ & & $-6.288(6.567)$ \\
\hline SHORT-RUN & & $-1.76^{* * * *}(0.406)$ \\
\hline ECT & $-1.497^{* * *}(0.303)$ & $-22.51(16.39)$ \\
D.CORR & $0.0692(0.327)$ & $2.315(2.248)$ \\
D.LOGGDPPC & $0.778(1.352)$ & $-4.193(7.608)$ \\
D.LOGINF & $-6.865(5.000)$ &
\end{tabular}



D.NR
$-0.003(0.041)$
$0.009(0.046)$
D.TOP
$-0.005(0.011)$
$0.003(0.008)$
D.PI
$-0.145 \quad(0.191)$
$0.0797(0.170)$
D.CORRSQ
$1.680(1.300)$
_Con
$-6.710(4.979)$
$-88.50(89.39)$

Hausman Test $\left(\mathrm{H}_{0}\right.$ : Difference in coefficient not systematic)

Prob $>$ Chi

0.999

1.000 